\title{
Occurrence of African cassava mosaic virus (ACMV) and East African cassava mosaic virus - Uganda (EACMV-UG) in Jatropha curcas
}

\author{
Rose Ramkat, Alberto Calari, Fatemeh Maghuly, Margit Laimer* \\ From IUFRO Tree Biotechnology Conference 2011: From Genomes to Integration and Delivery \\ Arraial d'Ajuda, Bahia, Brazil. 26 June - 2 July 2011
}

\begin{abstract}
Background
Jatropha curcas is a drought resistant shrub native in tropical America, now widely grown in many tropical and subtropical regions for biodiesel production [1]. First reports on virus infections in Jatropha indicated the occurrence of viruses closely related to Cassava mosaic virus in India, reaching a disease incidence from 25 to $47 \%$. This might represent a major constrain to the production of Jatropha in large scale [2]. The genome of Cassava mosaic geminiviruses (CMG) consist of two components termed DNA A and DNA B $(\sim 2.7-$ $3.0 \mathrm{~kb}$ ) [3]. Furthermore, Jatropha has been described as host of Cucumber mosaic virus (CMV) [2].
\end{abstract}

\section{Methods}

In this study we attempted to detect and molecularly characterize viruses infecting Jatropha in Eastern Africa (Kenya and Ethiopia). Detection methods will be valuable tools for early screening of plant viruses in order to make appropriate decisions and selection of planting material.

A total of 127 Jatropha samples from Ethiopia and Kenya (districts: Kakamega, Siaya, Busia and Nakuru showing typical virus symptoms and symptomless plants were used in this study. ELISA was performed to detect the presence of three RNA viruses: CMV, Cassava common mosaic virus (CsCMV) and Cassava brown streak virus (CBSV). PCR was performed using newly designed primers based on multiple alignments of full length DNA A sequences of geminiviruses available in the NCBI Genbank, reported to infect either Jatropha or cassava. This allowed to amplify the variable regions of

\footnotetext{
* Correspondence: m.laimer@iam.boku.ac.at

Plant Biotechnology Unit (PBU), Dept. Biotechnology, University of Natural Resources and Life Sciences, Muthgasse 18, 1190 Vienna, Austria
}

full length (2800 bp) and shorter sequences (380-1085 bp). PCR products were sequenced. A phylogenetic tree was constructed from multiple alignments by performing a heuristic search. Multiple alignments were analyzed by maximum parsimony with full-length DNA A using Phylogenetic Analysis Using Parsimony (PAUP) and a bootstrap analysis with 1000 replicates.

\section{Results and conclusions}

None of the Jatropha samples analysed was infected with the RNA viruses CBSV, CMV and CsCMV. PCR primers amplifying a $380 \mathrm{bp}$ fragment of $\mathrm{AC} 1, \mathrm{AC} 2$ and AC3 yielded positive results with $75 \%$ of the symptomatic samples from Kenya and further detected $20 \%$ of asymptomatic samples as positive. Furthermore, $61 \%$ of symptomatic Jatropha samples from Ethiopia were positive. Full length primers were able to detect $69 \%$ symptomatic Jatropha samples from Kenya, and also in 67\% of asymptomatic samples. PCR analyses of sample K1J5 amplified the expected $2.8 \mathrm{~kb}$ of a near full length DNA A component of the Begomovirus sequence and an additional shorter fragment.

Complete nucleotide sequences of 34 DNA A components typical of Begomoviruses were determined in the Kenyan samples. Thirty three sequences ranged from $2770 \mathrm{bp}$ to $2816 \mathrm{bp}$ while one (K1J5) consisted only of $1416 \mathrm{bp}$ and termed as a defective (Def) DNA. Phylogenetic analyses indicated that the defective molecule belongs to geminiviruses involved in CMG, representing a Def from DNA A of the bipartite Begomovirus ACMV. All viruses characterized in this study grouped with two previously identified Begomoviruses found in cassava in Western Kenya, namely EACMV - UG and ACMV. The Def DNA showed $96.6 \%$ sequence identity 
with the ACMV reference sequence [GenBank NC001467.1].

In this study, we report for the first time the detection of Begomovirus: ACMV and EACMV - UG in Jatropha from Kenya. From an evolutionary perspective, the phylogenetic data indicate that the virus isolates from the study were closely related to those isolated previously in Western Kenya from cassava $[4,5]$. Recombination and synergism that have long occurred in cassava [6,7] could have led to the recent spread of the virus in the field to infect Jatropha. Presence of EACMV - UG and ACMV on different Jatropha plants in the same field indicates the opportunity for mixed infections, hence offering good opportunities for more recombination to occur. EACMV - UG and ACMV are associated with severe synergistic epidemics on cassava. Synergism lead to a 10 - 50 fold increase in viral DNA accumulation which substantially increases the potential for a higher efficiency of vector transmission to even infect non cassava host plants [6,7]. This explain why EACMV - UG is the predominant virus in Jatropha. The deletions occurring in the Def DNA found in the study might affect the replication of the molecule and it might depend entirely on its helper virus for replication.

There is a possibility of Cassava mosaic virus in Jatropha being more wide spread than anticipated, since we have detected it also in Jatropha samples from Ethiopia.

\section{Acknowledgements}

The financial support of FFG project 820132 and Bioplant R \& D is kindly

acknowledged.

Published: 13 September 2011

\section{References}

1. Openshaw K: A review of Jatropha curcas: an oil plant of unfulfilled promise. Biomass Energy 2000, 19:1-15.

2. Raj SK, Snehi SK, Kumar S, Khan MS, Pathre U: First molecular identification of begomovirus in India that is closely related to Cassava mosaic virusand causes mosaic and stunting of Jatropha curcasL. Australas Plant Dis Notes 2008, 3:69-72.

3. Yadava P, Suyal G, Mukherjee SK: Begomovirus DNA replication and pathogenicity. Current Science 2010, 98:360-368.

4. Bull SE, Briddon RW, Ssserubombwe WS, Ngugi K, Markham PG, Stanley J: Genetic diversity and phylogeography of cassava mosaic virusesin Kenya. $J$ Gen Virol 2006, 87:3053-3065.

5. Stanley J, Gay MR: Nucleotide sequence of cassava latent virus DNA. Nature 1983, 301:260-262.

6. Zhuo X, Liu Y, Calvert L, Munoz C, Otim-Nape GW, Robinson DJ, Harrison BD: Evidence that DNA -A of a geminivirus associated with severe cassava mosaic disease in Uganda has arisen by interspecific recombination. J Gen Virol 1997, 78:2101-2111.

7. Harrison BD, Zhou X, Otim-Nape GW, Liu Y, Robinson DJ: Role of a novel type of double infection in geminivirus induced epidemic of severe cassava mosaic in Uganda. Ann App Biol 1997, 131:437-448.

8. Legg JP, Fauquet CM: Cassava mosaic geminiviruses in Africa. Plant Mol Biol 2004, 56:585-599.

9. Monde G, Walangululu J, Winter S, Bragard C: Dual infection by cassava begomoviruses in two leguminous species (Fabaceae) in Yangambi, North Eastern Democratic Republic of Congo. Arch Virol 2010, 155:1865-1869.
doi:10.1186/1753-6561-5-S7-P93

Cite this article as: Ramkat et al:: Occurrence of African cassava mosaic virus (ACMV) and East African cassava mosaic virus - Uganda (EACMVUG) in Jatropha curcas. BMC Proceedings 2011 5(Suppl 7):P93.

\section{Submit your next manuscript to BioMed Central and take full advantage of:}

- Convenient online submission

- Thorough peer review

- No space constraints or color figure charges

- Immediate publication on acceptance

- Inclusion in PubMed, CAS, Scopus and Google Scholar

- Research which is freely available for redistribution 